EPJ Web of Conferences 45, 01015 (2013)

DOI: $10.1051 /$ epjconf/20134501015

(c) Owned by the authors, published by EDP Sciences, 2013

\title{
Numerical Simulation of SNCR Technology with Simplified Chemical Kinetics Model
}

\author{
T. Blejchařr,a ${ }^{1, \text { D. Dolníčková }}{ }^{2, \mathrm{~b}}$ \\ ${ }^{1}$ VŠB-Technical University of Ostrava, Faculty of Mechanical Engineering, Department of Hydromechanics and \\ Hydraulic Equipment, tř. 17 listopadu 15/2172, Ostrava-Poruba, Czech Republic \\ ${ }^{2}$ VŠB-Technical University of Ostrava, Faculty of Mining and Geology, Institute of Environmental Engineering, \\ tř. 17 listopadu 15/2172, Ostrava-Poruba, Czech Republic
}

\begin{abstract}
The paper deals with numerical simulation of SNCR method. For numerical modelling was used CFD code Ansys/CFX. SNCR method was described by dominant chemical reaction, which were look up NIST Chemical database. The reactions including reduction of NOx and concentration change of pollutants, like $\mathrm{N} 2 \mathrm{O}$ and $\mathrm{CO}$ in flue gas too. Proposed chemical kinetics and CFD model was applied to two boilers. Both simulations were compared with experimental measurements. First simulation was used to validation of chemical mechanism. Second simulation was based on first simulation and it was used to verification of compiled SNCR chemical mechanism. Next the new variant of the reagent penetration lance was proposed and compared with the original variants.
\end{abstract}

\section{Introduction}

Power plant and/or heating plant $\mathrm{NO}_{\mathrm{x}}$ emission is actually solved the problem. $\mathrm{NO}_{\mathrm{x}}$ emission limit must be below $200 \mathrm{mg} / \mathrm{m}_{\mathrm{N}}{ }^{3}$ in compliance with EU legislation [4]. New energetic and thermal unit have to been guaranteed the $\mathrm{NO}_{\mathrm{x}}$ limit from 2008. Existing power and thermal unit will have to been guaranteed the $\mathrm{NO}_{\mathrm{x}}$ limit from 2016. Emission of $\mathrm{NO}_{\mathrm{x}}$ can be reduced by two different approaches. These approaches are called primary and secondary caution. Primary caution are based on modification of combustion process, e.g. zonal combustion, low emission burners, OFA etc. This process eliminates production of $\mathrm{NO}_{\mathrm{x}}$. Secondary caution is based on chemical destruction of $\mathrm{NO}_{\mathrm{x}}$ in flue gas. Chemical principle of secondary caution is reduction of $\mathrm{NO}_{\mathrm{x}}$ by $\mathrm{NH}_{2}^{-}$radical. Products of this reduction are molecular nitrogen $\mathrm{N}_{2}$ and water $\mathrm{H}_{2} \mathrm{O}$. Several modification of basic chemical principle exists, and we will deal with method called NOxOUT in this paper [6].

Basic principle of $\mathrm{NO}_{\mathrm{x}}$ reduction by $\mathrm{NH}_{2}{ }^{-}$radical is known from 70 years of 20 century. Dominant chemical reaction is very simply and is defined by following chemical formula [6], [1]

$$
\mathrm{NH}_{2}^{-}+\mathrm{NO} \rightarrow \mathrm{N}_{2}+\mathrm{H}_{2} \mathrm{O}
$$

\footnotetext{
a e-mail: tomas.blejchar@vsb.cz

b e-mail: dominika.dolnickova@vsb.cz
}

This reaction is dominantly occurred without catalyser in temperature window $850-1050{ }^{\circ} \mathrm{C}$, this reaction is called Selective Non-Catalytic Reduction (SNCR) [6]. Reaction is occurred with catalyser in temperature window 150$300{ }^{\circ} \mathrm{C}$ too, this reaction is called Selective Catalytic Reduction (SCR) [6].

\section{Basic Chemism of SNCR}

Generally three materials (reagents) are source of $\mathrm{NH}_{2}{ }^{-}$ radical. First material is Urea $\left(\mathrm{NH}_{2}\right)_{2} \mathrm{CO}$. Business name of SNCR method with Urea is NOxOUT [6]. Second material is Ammonia water $\mathrm{NH}_{4} \mathrm{OH}$. Business name of SNCR method with Ammonia water is DeNOx [6]. Relatively new third material is Cyanuric acid (HNCO)3. Business name of SNCR method with Cyan uric acid is RAPRENOx. Reaction scheme, which is shown in figure 1, illustrates individual reaction and relation between several materials. This SNCR scheme [2] is strongly simplified and about 150 reactions occur in reality.

Main problem of SNCR method is relatively narrow temperature window $\left(850-1050{ }^{\circ} \mathrm{C}\right)$. If the reagent is injected into colder temperature zone of furnace, the nitrogen oxides $\mathrm{NO}_{x}$ do not react with $\mathrm{NH}_{2}^{-}$radical, because the reaction rate is slow and high concentration of Ammonia $\mathrm{HN}_{3}$ is in flue gas. If the reagent is injected into warmer temperature zone of furnace, the $\mathrm{NH}_{2}^{-}$reacts with oxygen $\mathrm{O}_{2}$. So that the nitrogen oxides are not reduced but they are produced by combustion of 
ammonia. That is why the efficiency of SNCR is ca $65 \%$ and stoichiometric basis is ca 2.8 [6].

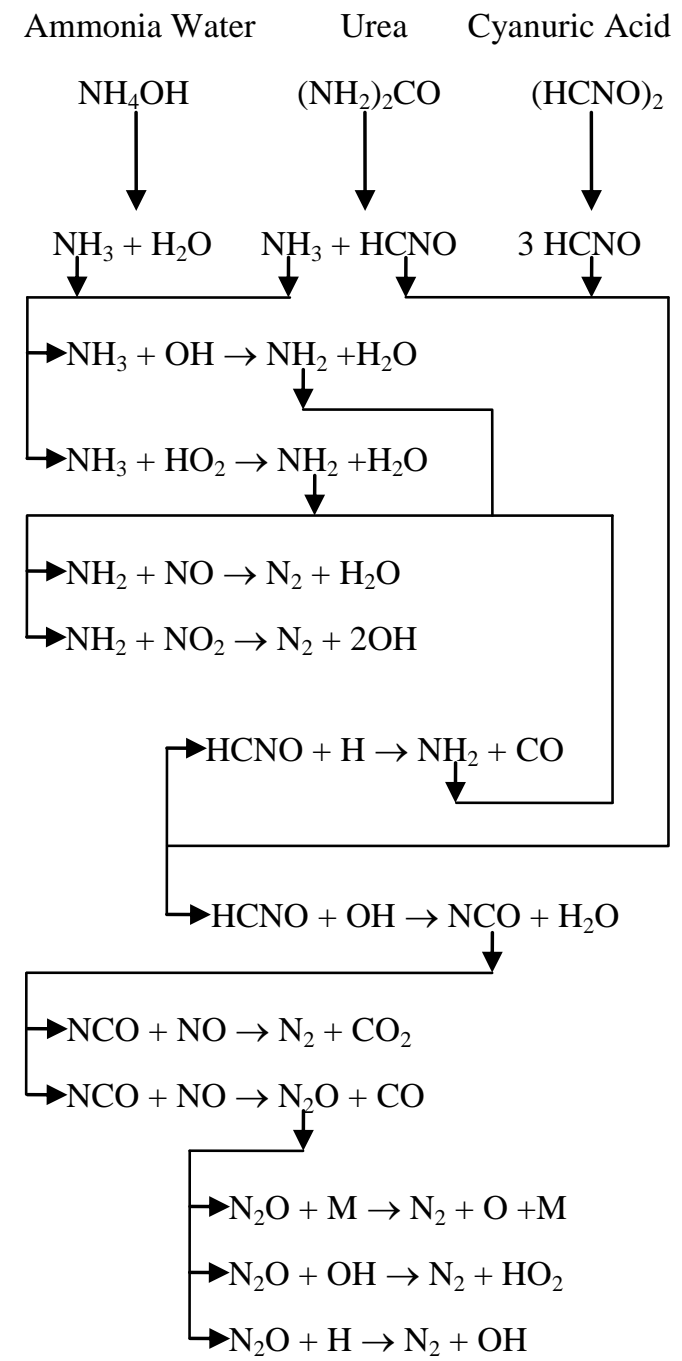

Fig. 1. Simply chemical mechanism of SNCR method [2].

\section{CFD Model of SNCR Chemism Kinetics}

The basic equation set which describes the bought regimes of flow represents application of conservation law. The law of mass, momentum and energy conservation is used to numerical modelling of flow [12]. The law of momentum conservation represents NavierStokes equation [12]. The Law of mass conservation represents continuity equation [12], and the law of energy equation represent energy equation [12]. The CFD code ANSYS CFX was user for simulations. Chemical reactions included in CFD are based on Arrhenius equation, which describes reaction rate [1], [12].

$$
k=A \cdot T^{\beta} \cdot \exp (-E / R T)
$$

where: $\mathrm{k}$ is reaction rate, $A$ is pre-exponential factor, $E$ is activation energy, $R$ is universal gas constant, $T$ is temperature, and $\beta$ is temperature exponent.

Arrhenius equation describes only rate of reaction. The chemic mechanism of every reaction must be specified by parent and children materials of reaction and stochiometric coefficients [12]. The chemical mechanism for SNCR with Urea was specified by following reactions. The chemical mechanism includes basic components of $\mathrm{NO}_{\mathrm{x}}$ pollutant, they are Nitric oxide $\mathrm{NO}$, Nitrogen dioxide $\mathrm{NO}_{2}$ and Nitrous oxide $\mathrm{N}_{2} \mathrm{O}$. Following reaction describes dominant reaction in SNCR process with Urea.

Primary breakdown process of urea solution droplets (thermal dissociation of Urea) is specified by two chemical reactions. Urea is injected into furnace as water solution. First the Urea solution is evaporated by reaction (4) so that Urea reacts with water. Than water is evaporated from droplet and only solid Urea is sublimated. Urea is thermal dissociated by reaction (3) respectively [2], [1].

$$
\begin{gathered}
\left(\mathrm{NH}_{2}\right)_{2} \mathrm{CO} \rightarrow \mathrm{NH}_{3}+\mathrm{HCNO} \\
\left(\mathrm{NH}_{2}\right)_{2} \mathrm{CO}+\mathrm{H}_{2} \mathrm{O} \rightarrow 2 \mathrm{NH}_{3}+\mathrm{CO}_{2}
\end{gathered}
$$

Nitric oxide $\mathrm{NO}$ and Nitrogen dioxide $\mathrm{NO}_{2}$ reduction process are described by following reaction (5), (6). These reactions specify the conversion of Nitric oxide $\mathrm{NO}$ and Nitrogen dioxide $\mathrm{NO}_{2}$ into Nitrogen $\mathrm{N}_{2}$ and Water $\mathrm{H}_{2} \mathrm{O}$. These reactions represent positive influence of SNCR method on $\mathrm{NO}_{\mathrm{x}}$ pollutant concentration in flue gas. Reactions rate are significant above temperature $850{ }^{\circ} \mathrm{C}$. Reactions are relatively slowly below temperature $850{ }^{\circ} \mathrm{C}$ that means the concentration of Ammonia $\mathrm{NH}_{3}$ increase in flue gas [2], [1].

$$
\begin{aligned}
& \mathrm{NH}_{3}+\mathrm{NO} \rightarrow \mathrm{N}_{2}+\mathrm{H}_{2} \mathrm{O} \\
& \mathrm{NH}_{3}+\mathrm{NO}_{2} \rightarrow \mathrm{N}_{2}+\mathrm{H}_{2} \mathrm{O}
\end{aligned}
$$

Next dominant reaction describes oxidation of Ammonia $\mathrm{NH}_{3}$. This reaction is significant above temperature $1050{ }^{\circ} \mathrm{C}$ and it is faster than reaction (5) and (6). Products of reaction are Nitric oxide NO and Water. This reaction represents higher level of temperature window for SNCR [2], [1].

$$
\mathrm{NH}_{3}+\mathrm{O}_{2} \rightarrow \mathrm{NO}+\mathrm{H}_{2} \mathrm{O}
$$

One problem of SNCR is second channel of primary breakdown (3). Urea seems to involve a significant emission of the pollutants, such as Carbon monoxide $\mathrm{CO}$ and Nitrous oxide $\mathrm{N}_{2} \mathrm{O}$. Productions of pollutants are described by following reactions [2], [1].

$$
\begin{gathered}
\mathrm{HCNO}+\mathrm{O}_{2} \rightarrow \mathrm{NCO}+\mathrm{H}_{2} \mathrm{O} \\
\mathrm{NCO}+\mathrm{NO} \rightarrow \mathrm{N}_{2} \mathrm{O}+\mathrm{CO}
\end{gathered}
$$

Production of Carbon monoxide $\mathrm{CO}$ and Nitrous oxide $\mathrm{N}_{2} \mathrm{O}$ is partially reduced by following reactions (10), (11). First reaction describes spontaneous thermal decomposition of Nitrous oxide $\mathrm{N}_{2} \mathrm{O}$. Second reaction describes combustion of Carbon monoxide $\mathrm{CO}$ [2], [1].

$$
\begin{aligned}
& \mathrm{N}_{2} \mathrm{O} \rightarrow \mathrm{N}_{2}+\mathrm{O}_{2} \\
& \mathrm{CO}+\mathrm{O}_{2} \rightarrow \mathrm{CO}_{2}
\end{aligned}
$$


Simplified SNCR reaction mechanism is described by previous reactions. Proposal mechanism does not include Ammonia radical NH2- that means the problematic nonstable transitional material is not necessary to specified. Reaction mechanism with NH2- radical is complicated. Proposed chemical mechanism for SNCR with Urea solution is relatively precise and simply. Complexity and computational intensity of CFD simulation is depended on number of materials and reaction. Reaction mechanism was proposed with reference to simulation speed and practise usability.

\section{Geometry of Boilers}

SNCR model was tested on two similar boilers with SNCR technology. The boilers are granulation type and as a fuel is used brown coal (lignite). Complete geometry of the both combustion chambers was created pursuant to drawing documentations. Ansys Design Modeler was used to 3D CAD design. The convection domain of combustion chambers were only used to model of SNCR process, and zone of super heater and heat exchanger was separated from all geometry of boilers respectively, see figure 2. Domain inlet (1) is located over zone of flame. Domain includes OFA (Over Flame Air) jet (2) too. The main heat transfer surfaces are plate super-heater (3) and pipe heat exchangers (4). Last heat exchanger is ECO (economiser) (5), which is located in second draught of boiler. Domain outlet (6) is located behind ECO [5].

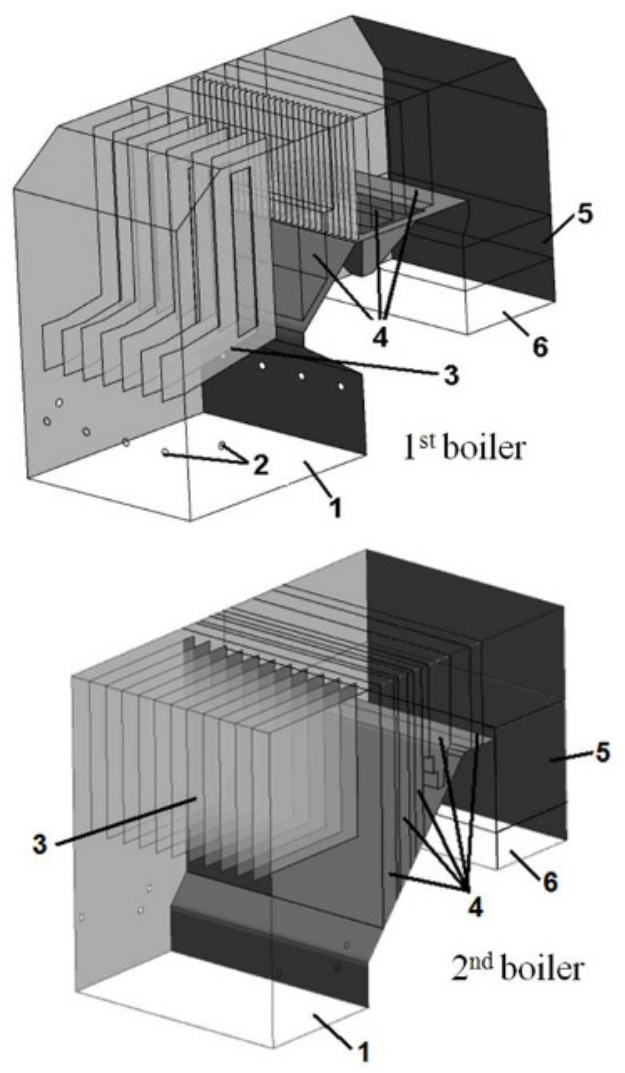

Fig. 2. Geometry of both boilers

This geometry was used to CFD simulation of SNCR process, because there are located the temperature
Windows $850-1050{ }^{\circ} \mathrm{C}$ and the reagent is injected into this zone of furnace. First geometry was used to validation of chemical mechanism. Second geometry was used to verification of compiled SNCR chemical mechanism.

\section{Results of CFD Simulations of SNCR}

CFD simulations were compared with results of experimental measurement. The CFD simulations and experimental measurements [5] were performed for boiled load $60,80,100 \%$. Baseline of $\mathrm{NO}_{\mathrm{x}}$ used in inlet boundary condition was specified on the basis of previous CFD simulation of coal combustion for both boilers and verified with the aid of analytics models [8], [9]. Location of Urea solution injection lances were designed with to view to measured temperature window. But the location is not optimum, it is due to design of boiler and manipulation restriction. The main results are wellarranged in Tab. 1 and 2 .

Table 1. Comparison of results, experimental measurement vs. CFD simulation, validation of SNCR

\begin{tabular}{|c|c|c|c|c|c|c|}
\hline & & \multicolumn{5}{|c}{$\left[\mathrm{mg} / \mathrm{m}_{\mathrm{N}}^{3}\right]$, at $6 \% \mathrm{O}_{2}, \mathrm{t}=0{ }^{\circ} \mathrm{C}$} \\
\hline & & $\mathrm{CO}$ & $\mathrm{NO}_{\mathrm{x}}$ & $\mathrm{NO}_{2}$ & $\mathrm{~N}_{2} \mathrm{O}$ & $\mathrm{NH}_{3}$ \\
\hline \multirow{2}{*}{$\begin{array}{c}\text { Without } \\
\text { SNCR }\end{array}$} & Meas. & 23.0 & 375.0 & 28.1 & 13.5 & 0 \\
\cline { 2 - 7 } & CFD & 23.7 & 392.3 & 27.2 & 16.0 & 0 \\
\hline With & Meas. & 41.3 & 192.0 & 16.4 & 31.8 & 1.2 \\
\cline { 2 - 7 } SNCR & CFD & 50.5 & 187.7 & 15.2 & 42.5 & 9.2 \\
\hline
\end{tabular}

Table 2. Comparison of results, experimental measurement vs. CFD simulation, verification of SNCR

\begin{tabular}{|c|c|c|c|c|c|c|}
\hline & & \multicolumn{5}{|c|}{$\left[\mathrm{mg} / \mathrm{m}_{\mathrm{N}}^{3}\right]$, at $6 \% \mathrm{O}_{2}, \mathrm{t}=0{ }^{\circ} \mathrm{C}$} \\
\hline & & $\mathrm{CO}$ & $\mathrm{NO}_{\mathrm{x}}$ & $\mathrm{NO}_{2}$ & $\mathrm{~N}_{2} \mathrm{O}$ & $\mathrm{NH}_{3}$ \\
\hline \multirow{2}{*}{$\begin{array}{l}\text { Without } \\
\text { SNCR }\end{array}$} & Meas. & 19.4 & 300.8 & 68.5 & 1.6 & 0 \\
\hline & CFD & 20.9 & 298.0 & 67.2 & 2.1 & 0 \\
\hline \multirow{2}{*}{$\begin{array}{c}\text { With } \\
\text { SNCR }\end{array}$} & Meas. & 45.8 & 127.5 & 64.8 & 42.3 & 25.2 \\
\hline & CFD & 46.2 & 138.7 & 56.0 & 21.3 & 26.2 \\
\hline
\end{tabular}

The measured data was defined as half hour time average. The CFD results were primarily computed as mass flow average of mass fraction. Both results (measured and CFD) were specified for normal condition, it is temperature $0{ }^{\circ} \mathrm{C}$, pressure $101325 \mathrm{~Pa}$ and $6 \%$ of $\mathrm{O}_{2}$ concentration in flue gas. Most significant mistake of CFD simulation is value of oxygen concentration in flue gas. This value is probably impressed with false air, which penetrates into furnace per wall leakage. It is problematic to specified sources of leakage and it is problem to include leakage to CFD simulation.

Main aim of CFD simulation is possibility to study aerodynamic in zone of Urea solution injection. Especially it can be monitored droplets trajectory, time of droplet live, concentration of each materials and reaction rate. Results of the CFD simulation can be used to prediction of SNCR technology efficiency too. 
We can see that reduction of NOx is dependent on production of Ammonia $\mathrm{HN}_{3}$. The Urea solution droplets are evaporated very quickly and the time of droplets live is approximately $1.5 \mathrm{~s}$, and the thermal breakdown of Urea solution is finished before first pipe heat exchanger. The increasing of the pollutants $\mathrm{CO}$ and $\mathrm{N}_{2} \mathrm{O}$ can be predicted too. The Ammonia slip is low, the value is practically immeasurable, that means the injection lance are suitable dislocated. In other words the Urea solution is injected into temperature window $850-1050{ }^{\circ} \mathrm{C}$. Low increase of pollutant $\mathrm{CO}$ and $\mathrm{N}_{2} \mathrm{O}$ predicate of high efficiency of $\mathrm{NO}_{\mathrm{x}}$ reduction too.

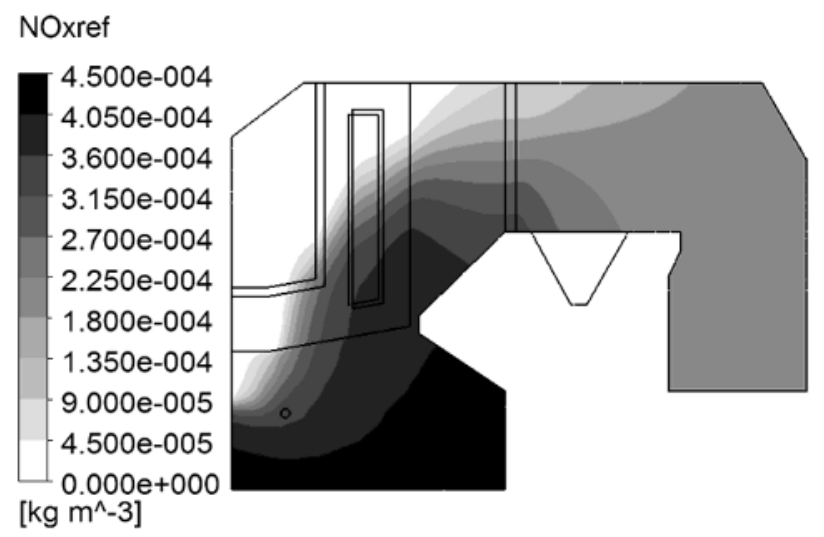

Fig. 3. Contour of $\mathrm{NO}_{\mathrm{x}}$ concentration for simulation of SNCR, $1^{\text {st }}$ boiler

NOxref

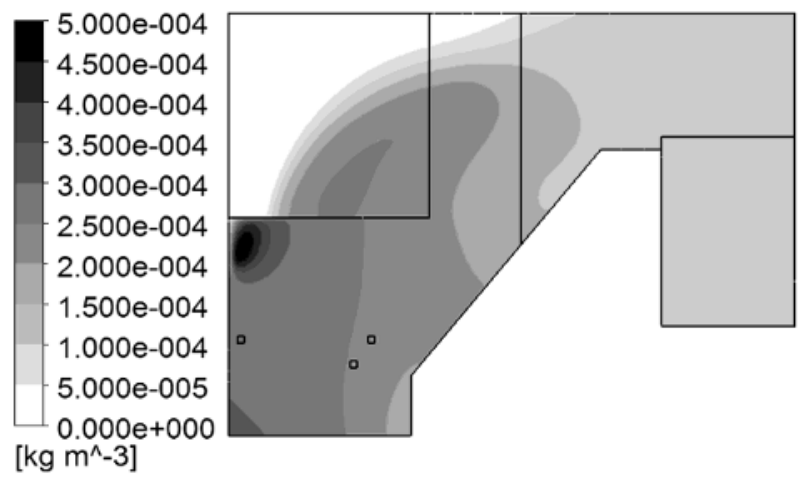

Fig. 4. Contour of $\mathrm{NO}_{\mathrm{x}}$ concentration for simulation of SNCR, $2^{\text {nd }}$ boiler

\section{New Injection Lance}

The main problem of SNCR technology is nonequilibrium penetration of flue gas in reacting zone with temperature window 850-1050 ${ }^{\circ} \mathrm{C}$. Commonly used lances with cone or plane nozzles are insert only ca $200 \mathrm{~mm}$ into combustion furnace. New type of the injection lance was engineered. The new lance spray the reagent deeply in combustion furnace and the flow of the reagent is dispersed into several nozzles. So reagent flow into one lance with one nozzle is in new lance distributed into few nozzles so that the reagent is sprayed more homogenous.

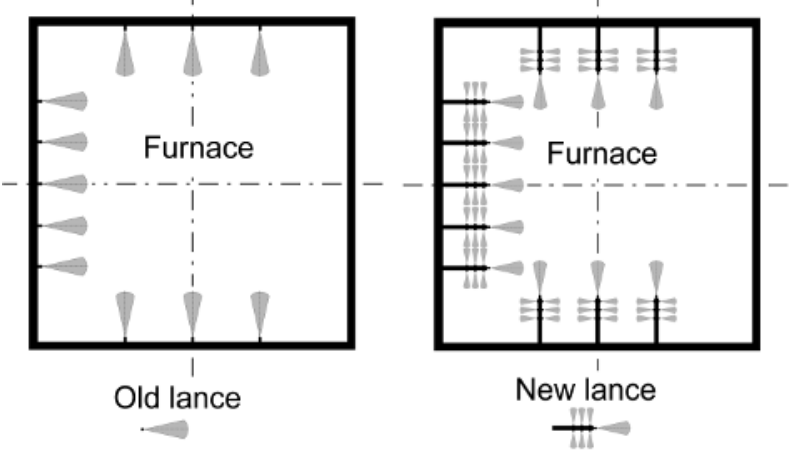

Fig. 5. Scheme of injection of reagent, old lance left side, new lance right side

The new lances guarantee better penetration of flue gas. CFD simulation with new lance was performed for both boilers. The results of CFD simulation with old and new lances were confrontation and the influence of new lance on SNCR technology was evaluated.

The CFD simulation confirmed the presumption about better spraying of the reagent. In the following picture we can see that new lances influences larger area. The reagent is sprayed in more points too. Maximum of the reagent mass fraction is lower for new lancet, which is good for chemical reaction.

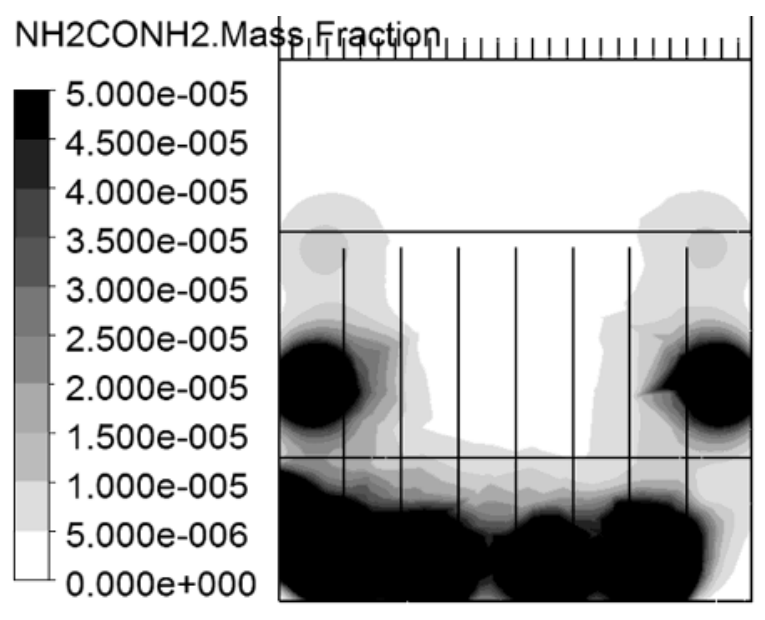

Fig. 6. Concentration of the urea, area influenced by reagent, old lances

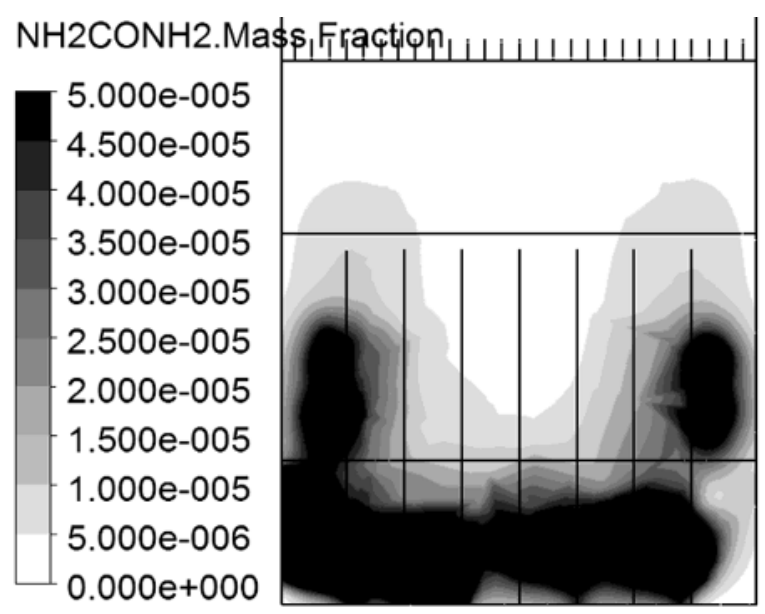

Fig. 7. Concentration of the urea, area influenced by reagent, new lances 
Table 3. Comparison of CFD simulation results, old and new lance, $1^{\text {st }}$ boiler

\begin{tabular}{|c|c|c|c|c|c|}
\hline & \multicolumn{5}{|c|}{$\left[\mathrm{mg} / \mathrm{m}_{\mathrm{N}}^{3}\right]$, at $6 \% \mathrm{O}_{2}, \mathrm{t}=0{ }^{\circ} \mathrm{C}$} \\
\hline & $\mathrm{CO}$ & $\mathrm{NO}_{\mathrm{x}}$ & $\mathrm{NO}_{2}$ & $\mathrm{~N}_{2} \mathrm{O}$ & $\mathrm{NH}_{3}$ \\
\hline $\begin{array}{c}\text { SNCR with } \\
\text { old lances }\end{array}$ & 50.5 & 187.7 & 15.2 & 42.5 & 9.2 \\
\hline $\begin{array}{c}\text { SNCR with } \\
\text { new lances }\end{array}$ & 44.2 & 176.5 & 10.1 & 25.4 & 3.2 \\
\hline
\end{tabular}

Table 4. Comparison of CFD simulation results, old and new lance, $2^{\text {nd }}$ boiler

\begin{tabular}{|c|c|c|c|c|c|}
\hline & \multicolumn{5}{|c|}{$\left[\mathrm{mg} / \mathrm{m}_{\mathrm{N}}^{3}\right]$, at $6 \% \mathrm{O}_{2}, \mathrm{t}=0{ }^{\circ} \mathrm{C}$} \\
\hline & $\mathrm{CO}$ & $\mathrm{NOx}$ & $\mathrm{NO}_{2}$ & $\mathrm{~N}_{2} \mathrm{O}$ & $\mathrm{NH}_{3}$ \\
\hline $\begin{array}{c}\text { SNCR with } \\
\text { old lances }\end{array}$ & 46.2 & 138.7 & 56.0 & 21.3 & 26.2 \\
\hline $\begin{array}{c}\text { SNCR with } \\
\text { new lances }\end{array}$ & 43.1 & 123.6 & 50.9 & 18.3 & 10.4 \\
\hline
\end{tabular}

\section{Discussion}

The goal of this study is the optimisation of SNCR technology. The CFD simulation was used for optimisation. The numerical simulation provided the sufficient information about the flow field in the combustion furnace, which is immeasurable in practical terms. The proposed CFD model can be used for prediction of the efficiency of SNCR technology and the design of injection lance dislocation can be verified. This model can be used for study of local aerodynamics and the trajectory of droplets as well as. The significant materials of $\mathrm{CO}, \mathrm{CO}_{2}, \mathrm{NO}, \mathrm{NO}_{2}, \mathrm{~N}_{2} \mathrm{O}$ a $\mathrm{NH}_{3}$ are included into the result of simulation.

The CFD model of SNCR was used to analyse the flow field in the reaction zone. Results of this simulation provide the information about the penetration of flue gas by reagent and the affected area, respectively. The main problem of SNCR with the currently used lance is a relatively low penetration of flue gas. This is the reason why the maximum efficiency is $65 \%$ only and stoichiometric basis. The new lance was designed. This lance should partially eliminate the disadvantage of the commonly used lances. The CFD simulation of SNCR with new lances was carried out and the results were compared. The results confirmed the theory: "If the reagent is better sprayed, then the efficiency of SNCR must be higher". The concentration of pollutants, e.g. $\mathrm{CO}, \mathrm{N}_{2} \mathrm{O}, \mathrm{NH}_{3}$ is lower, and the reduction of $\mathrm{NO}_{\mathrm{x}}$ is higher, too. The new lance will be produced and installed in real conditions. The effect of new lances will be verified and evaluated by experimental measurements.

\section{Acknowledgment}

The paper was prepared within the Project of MPO ČR TIP No. FI-IM4/193 "Research and Development of Nozzles for SNCR Technology in Power Engineering Focused on Elimination of Negative Effects of SNCR
Technology on the Environment (Emissions of $\mathrm{N}_{2} \mathrm{O}, \mathrm{CO}$ and $\left.\mathrm{NH}_{3}\right)^{\text {“ }}$

This work was supported by the European Regional Development Fund in the IT4Innovations Centre of Excellence project (CZ.1.05/1.1.00/02.0070)

\section{References}

1. A. Kohl, R. Nielsen, Gas Purification - Fifth Edition, Gulf Publishing Company, Houston, Texas, (1997) ISBN 0-88415-220-0

2. X. Hou, H. Zhang, M. Pilawska, J. Lu, G. Yue, The formation of $\mathrm{N}_{2} \mathrm{O}$ during the reduction of $\mathrm{NO}$ by $\mathrm{NH}_{3}$, Original Research Article, Fuel, 87 (2008)

3. B. von der Heide, Ist das SNCR-Verfahren noch Stand der Technik, Thomé-Kosmiensky, Michael Beckmann (Hrsg.): Energie aus Abfall - Band 4. Neuruppin: TK Verlag Karl Thomé-Kozmiensky, (2008) ISBN 978-3-935317-32-0

4. Ch. R. Choi, Ch. N. Kim, Numerical investigation on the flow, combustion and $\mathrm{NO}_{\mathrm{x}}$ emission characteristics in a $500 \mathrm{MWe}$ tangentially fired pulverized-coal boiler, Original Research Article, Fuel, 88 (2009)

5. M. Stáňa, B. Čech, J. Matoušek, O. Pumprla, Z. Szeliga, Reduction of $\mathrm{NO}_{\mathrm{x}}$ Emissions for Boilers G230 of Power Plant Opatovice, Original Research Article, Energetika a životní prostředí (2007) ISBN 978-80-248-1586-2

6. T. Blejchař, R. Malý, M. Maier, B. Čech, M. Stáňa, Z. Szeliga, Optimization of SNCR Technology via CFD simulation, In Archivum combustionis, Polska Akademia Nauk, Warszawa , Poland, 30 (2010) ISSN 0208-4198

7. Y. Lu, I. Hippinen, A. Jahkola, Control of $\mathrm{NO}_{\mathrm{x}}$ and $\mathrm{N}_{2} \mathrm{O}$ in pressurized fluidized-bed combustion Original Research Article, Fuel, 74 (1995)

8. M. Čarnogurská, M. Př́hoda, T. Brestovič, Modelling of nitrogen oxides formation applying dimensional analysis. Chemical and Process Engineering, 32-3 (2011) ISSN 0208-6425

9. L. Lazič, L. Lukáč, P. Lukáč, D. Hršak, Influence of the external recirculation of flue gas on reduction of $\mathrm{NO}_{\mathrm{x}}$ at propane butane combustion, Journal of International Scientific Publications: Ecology \& Safety, 5 (2011) ISSN 1313 - 2563

10. R. Rota, E. F. Zanoelo, Influence of oxygenated additives on the NOxOUT process efficiency, Original Research Article, Fuel, 82 (2003)

11. D. R. Tree, A. W. Clark, Advanced reburning measurements of temperature and species in a pulverized coal flame, Original Research Article, Fuel, 79 (2000)

12. Ansys, Inc., ANSYS CFX-Solver Theory Guide, (2010) 